American Journal of Applied Sciences 5 (10): 1409-1414, 2008

ISSN 1546-9239

(C) 2008 Science Publications

\title{
Empirical Analysis II: Business Cycles and Inward FDI in China
}

\author{
${ }^{1}$ Yahya Sharahili and ${ }^{2}$ Yao Liu \\ ${ }^{1}$ College of journalism and communication, Wuhan University, Wuhan, P.R. China \\ ${ }^{2}$ College of Economics, Huazhong University of Science and Technology, Wuhan, P.R. China
}

\begin{abstract}
It is well-known that the current speeding-up of globalization has been, on one hand, spreading macro economic effects around the world, while, on the other, fueling firms' activities of crossing national borders. Then, are there any links between these two influences? As we have concluded in previous research that inward FDI and business cycle development do pro-cyclically relate on Granger base, this paper will further discuss "how do they react to each other?" Again, we chose China as subject and employed the 1983 2004 authorized annual statistic data. By constructing an Endogenous Growth model, we, after processing Correlation Analysis and testing the coefficient significance of each variable, found out the original momentum of Chinese economic growth and explored whether there exist some long-term relationship through Johansen Co-integration Test
\end{abstract}

Key words: Business cycles; Inward FDI; Endogenous Growth; Johansen Co-integration Test.

\section{INTRODUCTION}

The issue of the relationship between inward FDI and business cycle development keeps hot since it was born. Why? One point is the significance of the topic, as for developed countries, inward FDI has become a necessary contributor to their national sustainable economic development, while for developing countries, it is an indispensable external power to upgrade their own economic growth especially under the backdrop of globalization. The other point is the differed research conclusions. Although many scholars studied it from various angles, their findings turned out to be different, sometimes even opposite. Thus, because of its significance but disagreements, it would maintain heating in the following long term.

Tracing back to 1990 s when FDI inward started burning in China, many foreign scholars have already did some relevant research. Some of them from host country (most are developing countries)' s viewpoint, explored how to take good advantage of FDI inward to improve national economy. For example, Abramovitz ${ }^{[2]}$ believed that the precondition for host countries to benefit from inward FDI is their Social Capability related to human resource level, the economic and political stability and the market openness, etc. Borensztein $^{[3]}$ et al indicated that only when the developing host countries reached the lowest level of human capital accumulation, FDI could exert higher producing efficiency. Some of them from investing country (normally developed countries)'s view, Markusen $^{[4]}$ emphasized long-term decisive factors, including absolute/comparative national factor endowment, market scale/distance and trading and investing cost, etc, and intended to answer why company becomes transnational and why transnational enterprises step into certain countries. Obviously, his research ignored the short-term economic fluctuation, which might directly induce company to commence overseas policies, could partly explain the instability of transnational activities.

Others from micro view analyzed the importance of company's differentiates when facing macro-economic strike. For instance, Bernanke ${ }^{[5]}$ et al pointed out that financial market frictions could, through net value effects, influence company's foreign investment activity. Although this kind of study concerned shorttern economic fluctuation, it cared more about company's own differentiates.

The purpose of this paper is to further discuss the impact of business cycle developments on inward FDI activities in China by employing the 1983 2004 authorized annual statistic data. Our research will proceed in three steps. Section 1, by deducing Barro's ${ }^{[6]}$ Production model to unveil potential relevant explanatory variables, will initially construct an Endogenous Growth model. In section 2, data and statistic description will be given. Section3 will focus on empirical analysis, including processing Correlation Analysis and testing the coefficient significance of each variable to find out the original momentum of Chinese economic growth, and exploring whether there exist some long-term relationship through Johansen Cointegration Test. Section 4 will draw a brief conclusion.

\section{MODEL DEDUCTION AND VARIABLE SPECIFICATION}

Model Deduction: Firstly, we reconstruct and dynamically transform Barro's Production Function into general production function:

$$
Y_{t}=A H_{t}^{\alpha} K_{t}^{1-\alpha}
$$

In which : $K=\left[\int_{0}^{N} x(j)^{1-\alpha} d j\right]^{\frac{1}{1-\alpha}}$

Corresponding Author: Yahya Sharahili, College of journalism, Wuhan University, Wuhan, China 


$$
N=n+n^{*}
$$

A is exogenous economic environmental factor (e.g. evolving of systems, transforming of policies, etc.). $\mathrm{H}$ represents human capital accumulation. $\mathrm{K}$ is unfinished products which could be understood as capital products and contains lots of various unfinished products with each represented by $x(j)$. The total domestically produced unfinished product is $\mathrm{N}, \mathrm{n}$ of which is produced by Domestic-funded Enterprises and $n^{*}$ of which is created by foreign-capital enterprises. According to this production function, we will start discussion from suppliers and demanders respectively. From suppliers' view, to provide unfinished products equals to offer the service flow of durable goods so as to gain rental profits. Thus, their optimization condition is to let marginal cost meet marginal benefit. Then the rental income from selling unfinished products equals the marginal productivity of producing those goods, that is:

$$
\begin{gathered}
m(j)=\frac{\partial y(j)}{\partial x(j)}=(1-\alpha) A H^{\alpha} x^{-\alpha} \\
\text { In which }: Y(j)=A H^{\alpha} X(j)^{1-\alpha}
\end{gathered}
$$

For small or developing countries, assume technology diffusion mostly attributes to Multinational Enterprises which hold advanced technology, rather than domestic R\&D. Thus, to absorb or adopt this kind of technology needs the host countries to offer technical supporting and related infrastructure, which is the socalled fixed costs F. Suppose F is the function of the gap between the current domestic foreign capital ratio and the general level of domestic technology. $F$ is negative to the former part $(n * / N)$ which means the bigger the proportion of foreign companies is, the lower the cost of absorbing technology will be, and is positive to the latter $\operatorname{part}\left(\mathrm{N} / \mathrm{N}^{*}\right)$,i.e. $\mathrm{N}^{*}$ represents the number of capital- producing companies from other countries, that is, the worse the host country's technology is the lower the absorbing cost would be.

Thus, for each period, the profit function of the unfinished goods supplier comes to:

$$
\begin{aligned}
& \lambda(j)=[(m(j)-1) x(j)]-F\left(n^{*} / N, N / N^{*}\right) \\
& F=F\left(n^{*} / N, N / N^{*}\right) \\
& \frac{\partial F}{\partial\left(n^{*} / N\right)}<\frac{\partial F}{\partial\left(N / N^{*}\right)}>0
\end{aligned}
$$

To a certain extent, the unfinished goods supplier, as Monopoly, would set price $\mathrm{m}(\mathrm{j})$ in every period to optimize it's benefits $P(j)$. Thus, the derived monopoly price is:

$$
\begin{aligned}
& x(j)=H A^{\frac{1}{\alpha}}(1-\alpha)^{\frac{2}{\alpha}} \\
& m(j)=(1-\alpha)^{-1}
\end{aligned}
$$

To dynamically transform it, we can get:

$\lambda(j)=\int_{0}^{\infty}[m(j) x(j)-x(j)] e^{-r(s-t)} d s-F\left(n^{*} / N, N / N^{*}\right)$

Suppose to produce the unfinished goods suffers no entrance barrier, then, from a long-term stand, $P(j) t$ tends to be zero。 Thus, we can compute interest rate $r$ as :

$$
\begin{aligned}
& r=A^{\frac{1}{\alpha}} \phi(F)(\bullet)^{-1} H \\
& \phi=\alpha(1-\alpha)^{\frac{2-\alpha}{\alpha}}
\end{aligned}
$$

Same like other Endogenous Growth models, this one should also be finalized under some Constraint Condition resolving Consumption Function according to Ramsey, by employing Pontrygain Maximum Principle, that is, to optimize consumers' utility and realize equilibrium.

Ramsey Consumption Function:

$$
U_{t}=\int_{t}^{\infty} \frac{c_{t}^{1-\alpha}}{1-\sigma} e^{-\rho(s-t)} d s
$$

Where $c(t)$ is consumption at time $t ; \rho$ is rate of discount, which indicates the patience of people's delaying consumption and the higher the $\rho$ value, the lower the consumers' evaluation towards future Consumption compared with present consumption; $\sigma$ is the negative value of the Marginal Effect Elasticity or called relative risk-averse coefficient $(\sigma>0)$. By employing Pontrygain Maximum Principle, we can then obtain the optimal balanced growth path of the whole economic system as follows:

$$
g=\frac{\partial c(t) / \partial t}{c(t)}=\frac{1}{\sigma}(r-\rho)=\frac{1}{\sigma}\left[A^{\frac{1}{\alpha}} \phi F(\bullet)^{-1} H-\rho\right]
$$

Thus, we can draw conclusion from this model that the balanced economic growth rate primarily depends on: the evolving of systems (A), the human capital accumulation $(\mathrm{H})$, the cost of 
introducing/absorbing/imitating advanced technologies $(F)$, and the value of the time discount rate $(\rho)$.

The growth rate is positive to $\mathrm{H}$ and negative to $\mathrm{F}$ and $\rho$. Thus, 1) the higher production efficiency of human capital department, the bigger the human capital accumulation, then the faster the economic growth;2) the more the host country absorbs FDI, the narrower the technical gap, the lower the cost of acquiring Foreign technology, then the higher the growth rate will be; 3 ) the higher the current deposit rate (i.e. the more patient that consumers could delay consumption), the higher the growth rate will be.

Variable Specification: Based on the conclusion deduced from the theoretical model above, we construct our Linearized Econometric Model as follows:

$$
L n G=c_{o}+c_{1} F G D P+c_{2} H+c_{3}(F G D \ddot{P} H)+c_{4} G Y+\xi
$$

The specific variables are:

LnG: the natural logarithm value of The Annual GDP per capita in each region (unit: yuan RMB), representing the growing speed of each region. In this thesis, LnG is dependent variable and others are independent variables.

FGDP: the ratio of annual inflow of FDI (unit: 10000 USD) in each region to annual GDP (unit: 0.1 bn $\mathrm{RMB}$ ) of that region. Theoretically, FGDP is positive to LnG, which means the effects of Technology Spillovers of FDI on economic growth.

$\mathrm{H}$ : the human capital accumulation in each region. As there is no authorized method so far in China to measure human capital and FDI inflow requires highquality human capital, this thesis takes annual highschool-student proportion as $\mathrm{H}$. In details, $\mathrm{H}$ is the ratio of the annual high-school-student number in each region to the total regional population in the end of that year. Theoretically, if the economic growth belongs to be intensive, $\mathrm{H}$ would be positively related to LnG.

FGDP*H: The product of FDI flow and highschool-student proportion. If it's coefficient is positive, it means to employ the technology spillovers of FDI needs to combine human capital.

GY: the share of state-owned Industrial Output Values in Gross Industrial Output Values in each region. For computing convenience, we use GY to roughly reflect Chinese system like openness etc.. Theoretically, GY is supposed to be negative towards LnG.

\section{DATA AND STATISTICS DESCRIPTION}

The data and statistics to be used in the paper are mainly from two sources: the National Bureau of Statistica of China, available at www. stats. gov. cn., and China Compendium of statistics 1949-2004 compiled by the National Bureau of Statistica of China.

\section{RESULTS AND DISCUSSION}

As we have concluded in previous research that Chinese inward FDI and business cycle development do pro-cyclically relate on Granger base, this Part will further discuss "how do they react to each other?" Again, we chose China as subject and employed the 1983 2004 authorized annual statistic data. By constructing an Endogenous Growth model seen above, we, after processing Correlation Analysis and testing the coefficient significance of each variable, found out the original momentum of Chinese economic growth and then explored whether there exists some long-term relationship through Johansen Co-integration Test.

Correlation Analysis on Chinese Inward FDI and Business Cycle Development: Firstly, let's take a close look at the correlation-ship between Chinese inward FDI and business cycle development. In order to clearly present the correlation between business cycles and each variable, the following tends to evaluate it by escalating the number of explanatory variables and erasing the insignificant parameters (if insignificant parameters do exist). The detailed results are shown in Table 1.

See line I in table 1 chose FGDP as solo explanatory variable, and the result shows it is significant to $\mathrm{LnG}$ at $1 \%$ level, with a positive correlation. Line III took in $\mathrm{H}$, which is positively correlated to FGDP at the significance level of $1 \%$ from the result. Line IV further added $\mathrm{FGDP}^{*} \mathrm{H}$, with all explanatory variables keeping significant. And then conclude GY in line V. Through this approach, it is convenient to unveil the original momentum of Chinese economic growth.

The results indicate that:

(1) the share of inward FDI in GDP in one region has a very significant impact on the growth of the regional per capita GDP. To better analyze the growth effect of FDI, line II in Table 1 calculated the natural logarithm of FGDP, obtaining a coefficient estimate 0.36 , which indicates that the share of inward FDI in regional GDP increases one \%, the regional per capita GDP will correspondingly increase $0.36 \%$. As R2 is 0.79 which means the change of Independent Variable explained $79 \%$ of the change of the dependent variable, it indicates inward FDI relies on the host country's R\&D development and technology innovation while promoting technology diffusion.

(2) the human capital accumulation $H$ has passed significance tests almost in all estimating models, which means Chinese economy is now moving on the road of intensive growth and the promoting influence of human capital accumulation on economic growth is gradually fading in. Nowadays, since the S\&T 
transferring capability of Chinese University is increasingly strengthened and related systems are much more improved, the human capital accumulation in each region is reflecting their local S\&T strength and ability of transferring it into productivity.

(3) the negative correlation between FGDP* $\mathrm{H}$ and LnG indicates that regional positive inward FDI hasn't realize dilution effects to improve the balanced regional economic development by integrating with human capital, which from another perspective illuminates that the size of regional human capital accumulation seems have no necessarily positive relationship with the degree of FDI technology dilution effects.

(4) GY passed the significance testing, which means the share of state-owned Industrial Output Values in Gross Industrial Output Values is negative to the economic growth. Oversized state-owned industry share, to certain extend, has negative effects on economy development. According to the result in Table 1 , if the share of state-owned industry declines $1 \%$, LnG will correspondingly increase $3.5 \%$, which from an opposite angle indicates that transforming into market economic system would bring in an obvious growth effects to Chinese economic development.

Unit Root Test: The precondition of applying traditional regression approach to evaluate and verify is to assure the object time series data is stable, or there could turn out Spurious Regression. Because most of economic time series are unstable, it is necessary to progress Unite Root Testing before continuing Cointegration regression. Here Augmented Dickey-Fuller (ADF) Unit Root Testing approach is employed, and the Eviews 3.1 output is presented in Table 2

Table 1: Analysis on FDI and decisive factors in economic growth

\begin{tabular}{|c|c|c|c|c|c|}
\hline & I & II & III & IV & $\mathrm{V}$ \\
\hline \multirow{3}{*}{$\begin{array}{c}\text { constan } \\
\mathrm{t}\end{array}$} & $9.468518155^{*}$ & $8.679661 *$ & $8.983137 *$ & $8.597375^{*}$ & $11.51549 *$ \\
\hline & $(0.120906001)$ & $(0.116881)$ & (0.092594) & $(0.126252)$ & $(0.479222)$ \\
\hline & (78.31305349) & $(74.26067)$ & (97.01627) & $(68.09668)$ & $(24.02954)$ \\
\hline \multirow{3}{*}{ FGDP } & $0.036339075^{*}$ & & $0.025853^{*}$ & $0.039803^{*}$ & 0.011114 \\
\hline & $(0.004002469)$ & & $(0.002799)$ & $(0.004204)$ & $(0.005687)$ \\
\hline & $(9.07916402)$ & & $(9.237684)$ & $(9.4677)$ & $(1.954134)$ \\
\hline \multirow{3}{*}{$\begin{array}{l}\operatorname{Ln}(\mathrm{FG} \\
\mathrm{DP})\end{array}$} & & $0.359726^{*}$ & & & \\
\hline & & $(0.043217)$ & & & \\
\hline & & $(8.323726)$ & & & \\
\hline \multirow{3}{*}{$\mathrm{H}$} & & $228.0225^{*}$ & $228.7143^{*}$ & $388.555 *$ & 80.10582 \\
\hline & & $(25.0582)$ & $(23.4856)$ & (43.77302) & $(60.48824)$ \\
\hline & & $(9.099717)$ & $(9.738489)$ & $(8.876587)$ & $(1.32432)$ \\
\hline \multirow{3}{*}{$\begin{array}{l}\mathrm{H}^{*} \mathrm{FG} \\
\mathrm{DP}\end{array}$} & & & & $-4.513036^{* *}$ & -0.591471 \\
\hline & & & & (1.078757) & $(1.062291)$ \\
\hline & & & & $(-4.183553)$ & $(-0.556788)$ \\
\hline \multirow{3}{*}{ GY } & & & & & $-3.504381 *$ \\
\hline & & & & & $(0.562801)$ \\
\hline & & & & & $(-6.226681)$ \\
\hline $\mathrm{R} 2$ & 0.551633184 & 0.794184 & 0.816013 & 0.852956 & 0.908975 \\
\hline $\begin{array}{l}\text { Adjuste } \\
\text { d R2 }\end{array}$ & 0.544941142 & 0.787947 & 0.810437 & 0.846064 & 0.903196 \\
\hline $\begin{array}{c}\text { F- } \\
\text { Value }\end{array}$ & 82.43122 & 127.3373 & 146.36 & 123.7482 & 157.2794 \\
\hline $\begin{array}{l}\text { Sample } \\
\text { size }\end{array}$ & 69 & 69 & 69 & 68 & 68 \\
\hline
\end{tabular}


From the results, the ADF observation of real GDP growth rate LNSGDP, -0.316390 , is larger than the critical values at each level, thus, the NULL hypothesis of no unit root should be rejected, that is, this time series does exist unit root and it is unstable. Following the same logic, the real inward FDI growth rate LNSFDI series also exists instability. Therefore, in order to further study, we appeal to One Order Difference for each time series, noted as DLNSGDP and DLNSFDI respectively.

Then the new results show that the ADF observation of DLNSGDP, -3.672613, is at least smaller than the critical value -2.6552 at $5 \%$ level and the ADF observation of DLNSFDI, -2.683361 , is at least smaller the critical value -2.6552 at $10 \%$ level. Thus, after differentiated, the two object time series, under some significance level, do not exist unit root, that is, DLNSGDP and DLNSFDI series are stable now.

Co-integration Test: Based on the analysis above, as DLNSGDP and DLNSFD are stable series, this section will move onto Co-integration test to prove whether there exists some long-term relationship between them. Here, Johansen co-integration method is applied and the Eviews3.1 output can be seen as Fig.1.

Suppose time limit from period 1 to period 4, with a sole period 5 lag. The outcome shows the two variables do have co-integration relationship. For details, the up part of Fig.1 gives out the co-integrating results. The first row verifies there is no co-integration, with NULL hypothesis "no long-term equilibrium relation. But as the probability rate 49.77833 is bigger than 20.04 at the significance level of $1 \%$, the Null hypothesis should be rejected, that is, there is co-integration existing. The NULL hypothesis in the second low is there at most exists one co-integration vector. As the probability rate 0.257148 is even smaller than 3.76 at the significance level of 5\%, the NULL should be accepted.

The middle part (Un-normalized Co-integrating Coefficients) gives out the long-term relationship of the two un-normalized variables. And the down part (Normalized Co-integrating Coefficients) shows the normalized co-integration variables under the precondition of one co-integration relation existing, that is, DLNSGDP $=-1.26+17.03$ DLNSFDI
Table 2: Augmented Dickey-Fuller Unit Root Test

\begin{tabular}{|c|c|c|c|}
\hline \multicolumn{4}{|c|}{ Augmented Dickey-Fuller Unit Root Test } \\
\hline : & $\begin{array}{c}\text { ADF } \\
\text { observation }\end{array}$ & \multicolumn{2}{|c|}{$\begin{array}{l}\text { Significance level } \\
\text { and critical value }\end{array}$} \\
\hline \multirow{3}{*}{ 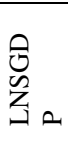 } & \multirow{3}{*}{-0.316390} & $1 \%$ C.V. & -3.8067 \\
\hline & & $5 \%$ C.V. & -3.0199 \\
\hline & & $10 \%$ C.V & -2.6502 \\
\hline \multirow{3}{*}{ 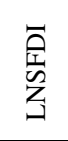 } & \multirow{3}{*}{-1.884615} & $1 \%$ C.V. & -4.5348 \\
\hline & & $5 \%$ C.V. & -3.6746 \\
\hline & & $10 \%$ C.V & -3.2762 \\
\hline \multirow{3}{*}{ 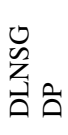 } & \multirow{3}{*}{-3.672613} & $1 \%$ C.V. & -3.8304 \\
\hline & & $5 \%$ C.V. & -3.0294 \\
\hline & & $10 \%$ C.V & -2.6552 \\
\hline \multirow{3}{*}{$\begin{array}{l}\frac{\omega}{\sqrt{2}} \\
Z_{1} \\
\bar{\Delta}\end{array}$} & \multirow{3}{*}{-2.683381} & $1 \%$ C.V. & -3.8304 \\
\hline & & $5 \%$ C.V. & -3.0294 \\
\hline & & $10 \%$ C.V & -2.6552 \\
\hline
\end{tabular}

\begin{tabular}{|c|c|c|c|c|}
\hline \multicolumn{5}{|c|}{ Johansen Cointegration Test } \\
\hline \multicolumn{5}{|c|}{$\begin{array}{l}\text { Date: } 04 / 13 / 07 \text { Time: } 22: 28 \\
\text { Sample: } 19832004 \\
\text { Included observations: } 15 \\
\text { Test assumption: Linear deterministic trend in the data } \\
\text { Series: DLNSFDI DLNSGDP } \\
\text { Lags interval: } 1 \text { to } 3,5 \text { to } 5\end{array}$} \\
\hline Eigenvalue & $\begin{array}{l}\text { Likelihood } \\
\text { Ratio }\end{array}$ & $\begin{array}{c}5 \text { Percent } \\
\text { Critical Value }\end{array}$ & $\begin{array}{c}1 \text { Percent } \\
\text { Critical Value }\end{array}$ & $\begin{array}{l}\text { Hypothesized } \\
\text { No. of CE(s) }\end{array}$ \\
\hline $\begin{array}{l}0.963169 \\
0.016997\end{array}$ & $\begin{array}{l}49.77833 \\
0.257148\end{array}$ & $\begin{array}{r}15.41 \\
3.76\end{array}$ & $\begin{array}{r}20.04 \\
6.65\end{array}$ & $\begin{array}{c}\text { None } \\
\text { At most } 1\end{array}$ \\
\hline \multicolumn{5}{|c|}{$\begin{array}{l}* \text { (*) denotes rejection of the hypothesis at } 5 \%(1 \%) \text { significance level } \\
\text { L.R. test indicates } 1 \text { cointegrating equation(s) at } 5 \% \text { significance level }\end{array}$} \\
\hline \multicolumn{5}{|c|}{ Unnormalized Cointegrating Coefficients: } \\
\hline $\begin{array}{r}\text { DLNSFDI } \\
-2.675612 \\
1.405122\end{array}$ & $\begin{array}{r}\text { DLNSGDP } \\
45.57449 \\
16.61709\end{array}$ & & & \\
\hline \multicolumn{5}{|c|}{ Normalized Cointegrating Coefficients: 1 Cointegrating Equation(s) } \\
\hline $\begin{array}{l}\text { DLNSFDI } \\
1.000000\end{array}$ & $\begin{array}{c}\text { DLNSGDP } \\
-17.03330 \\
(0.76522)\end{array}$ & $\begin{array}{c}C \\
1.258575\end{array}$ & & \\
\hline Log likelihood & 92.03224 & & & \\
\hline
\end{tabular}

Fig.1: Johansen Co-integration Test and Eviews3.1 Results

\section{CONCLUSIONS}

In this paper, we have furthered our discussion about analyzing the relationship between business cycle movements and multinational activities, especially inward FDI by using Chinese data and statistics, which are annual and cover a time period of 22 years (19832004). And the conclusions can be drawn as 1) to better use inward FDI needs a certain accumulating level of human capital, needs the inward FDI to combine with the host countries' human resource, and needs a sound 
macro environment; 2) firms' (foreign) activities do have a long-term relatively-stable relationship with business cycle developments.

\section{REFERENCES}

1. Qiyun Fang, Yao Liu, 2007. Empirical Analysis: Business Cycles and Inward FDI in China, American Journal of Applied Sciences, 4(8): 800804

2. Abramovitz,M., 1986. Catching up, forging ahead and falling behind, The Journal of Economic History, 46: 385-406.

3. Borensztein E., De Gregorio, J.Lee, J.W., 1998. How does foreign direct investment affect economic growth, Journal of International Economics, 45: 115-135.
4. Markusen, J. R., 2002. Multinational Firms and the Theory of International Trade. Cambridge, Mass.: MIT Press.

5. Bernanke, B. S., M. Gertler, and S. Gilchrist, 2000. The Financial Accelerator in a Quantitative Business Cycle Framework. In J. Taylor and M. Woodford (eds.), Handbook of Macroeconomics. Amsterdam: North-Holland.

6. Barro, R. J. and Sala-I-Martin, 1995. Economic Growth, McGraw-Hill, Inc.

7. Christiano, L. J., and T. J. Fitzgerald, 1998. The Business Cycle: It's Still a Puzzle. Economic Perspectives, 4: 56-83.

8. Chuang,Y.C., Lin.C.M.,1999. Foreign Direct Investment, R\&D and Spillover Efficiency: Evidence from Taiwan's Manufacturing Firms. The Journal of Development Studies, 35: 117-137. 